УДК 378.016:81'25

UDC 378.016:81'25

DOI: $10.31475 /$ ped.dys.2020.29.10

IРИНА САВКА,

кандидат педагогічних наук, доцент

(Украӥна, Львів, Львівський національний університет ілені Івана Франка, вул. Університетська, 1)

IRYNA SAVKA,

Candidate of Pedagogical Sciences, Associate Professor (Ukraine, Lviv, Ivan Franko National University of Lviv, Universytetska St., 1)

ORCID: 0000-0002-3213-0921

\title{
Педагогічні умови реалізації професійної підготовки майбутніх перекладачів на основі інтегративного підходу
}

\section{Pedagogical Conditions for the Realization of Professional Training of Future Translators on the Basis of the Integrative Approach}

У статті обтрунтовано педагогічні умови реалізації профбесійної підготовки майбутніх перекладачів на основі інтегративного підходу. Доведено, що для профбесійної підготовки майбутніх перекладачів необхідна орієнтація на профбесійно спряловану інтеграцію знань $i$ вмінь; забезпечення інтеграції проббесійної фбахової підготовки фбахівиів з перекладу; реалізація інтегрованого змісту, методів $i$ бборм реалізацї̈ профбесійної спрямованості гуманітарних дисииплін для студентів спеціальності «Філолог»). Зазначено, що одним із завдань удосконалення проббесійної підготовки проббесійних перекладачів е фбормування у майбутніх перекладачів проббесійно-орієнтованої лексичної обізнаності. З'ясовано, що проббесійні уління перекладача полягають у гнучкому й успішному виконані профбесійних обов'язків в нестандартних, незвичайних, різноманітних ситуаціях. Визначено, що однією з основних фбункцій профбесійної діяльності перекладача є комунікативна.

Ключові слова: педагогічні умови, профбесійна підготовка, майбутні перекладачі, інтегративний підхід

The article substantiates the pedagogical conditions for the implementation of professional training of future translators on the basis of an integrative approach. It is proved that for the professional training of future translators it is necessary to focus on professional integration of knowledge and skills; ensure the integration of professional training of translation specialists; implementation of integrated content, methods and forms of implementation of the integrative approach in training for the students of the specialty "Philology). It is noted that one of the tasks of improving the professional training of professional translators is the formation future translators' professionally-oriented lexical awareness. The professional skills of a translator are found to be flexible and successful in performing professional duties in non-standard, unusual, diverse situations. It is determined that one of the main functions of a translator's professional activity is communicative. The article justifies the pedagogical conditions of professional training of future translators based on an integrative approach aimed to ensure internal professional integration of knowledge and skills of linguistic disciplines (general foreign language subsystem of the professional training for a future translator), the provision of external professional integration of the knowledge and skills of the professional foreign language training, the formation of an integrated training system of a future translator. The article shows the features of the integration of knowledge and skills for future translators such as the integration of knowledge and skills in foreign languages learning, which helps to optimize the theoretical and practical components of the future translators training; the doubled integration of knowledge and helps to update the content of the professional training; the provision of the constant updating of knowledge and skills of languages by the specialist in translation.

Keywords: professional training, future translators, pedagogical conditions, professional activity, integration of knowledge.

Вступ / Introduction. Інтенсивний розвиток міжнародних відносин України з европейським економічним та політичним простором, широкі професійні можливості населення суттево підвищуе значущість фахових перекладачів, які представляють важливу ланку між нашою державою та світовими лідерами на міжнародній арені. Цей фактор висуває нові вимоги до професійної 
підготовки фахівців, які вміло забезпечують обмін інформації між представниками різних культур. Професійна кваліфікація таких фахівців передбачає їхню високу продуктивність, гнучкість, здатність адаптуватися до швидких змін у суспільстві, а також розроблення якісно нових підходів до їхньої професійної підготовки. У сучасні освітні стандарти внесено соціально обтрунтовані вимоги до дипломованого спеціаліста, здатного компетентно вирішувати складні питання міжнародного та державного значень. Однак, забезпечення високого рівня їх реалізації на практиці залишаеться актуальним завданням вищої професійної освіти. Удосконалення професійної підготовки професійних перекладачів зумовлено багатьма об’ективними і суб’ективними чинниками, серед яких - динамічний розвиток світового ринку праці, які вносять суттеві корективи в структуру професійної підготовки та професійної діяльності перекладачів. Майбутньому перекладачеві необхідно виконувати висококваліфіковану аналітичну й організаційну роботу, правильно оцінювати ситуацію, обтрунтовано й чітко висловлювати власну точку зору.

У педагогіці накопичено значний досвід досліджень проблем інтеграції (Гончаренко С., 1997; Гребенніков А., 2012; Козловська І., 2008 та ін.), підготовці перекладачів (Гавриленко Н., 2013; Долинський Є., 2013; Мартинюк О., 2012; Моцар М., 2018; Наказний М., 2015 та ін.), професійна підготовка (Ковязіна О., 2000; Колодій I., 2009; Соколова I., 2008 та ін.). Водночас, поза увагою дослідників залишилось обгрунтування педагогічних умов формування системи інтегрованих знань та умінь майбутніх перекладачів.

Мета та завдання / Aim and Tasks. Обгрунтування педагогічних умов професійної підготовки майбутніх перекладачів на основі інтегративного підходу.

Методи / Methods. У дослідженні нами використані такі методи: аналіз сутності професійної підготовки та інтегративного підходу у професійній підготовці фрахівців, класифікація принципів навчання, порівняння та асиміляція різних підходів до професійної підготовки, виділення причин низького рівня професійної підготовки, узагальнення результатів дослідження. Нами використана методика цільового опитування викладачів для виявлення рівня інтегрованих дисциплін.

Результати / Results. Професійна діяльність випускників напряму підготовки «Філологія» спрямована на вивчення іноземної мови на високому рівні для застосування ії у своїй професійній діяльності. Випускники спеціальності «Філологія» можуть реалізуватися у різних сферах діяльності, одна з яких є переклад. Професія перекладача вимагає широких знань (лінгвістичних, екстралінгвістичних, загальнокультурних з країнознавства, історії і літератури, а також знань, необхідних для перекладу в спеціальних галузях - економіці, юриспруденції, політиці, освіті, медицині тощо) (Латишев Л., 1999). Професійний світогляд перекладача - це система узагальнених поглядів на світ професії, яка динамічно розвиваеться, її роль і місце в сощіумі, що визначають ставлення до галузі міжкультурної, іншомовної і міжособистісної комунікації та до самого себе як суб'єкта професійної перекладацької діяльності. Студенти отримують теоретичні знання та практичні навички, необхідні для їх професійної діяльності.

Завдання формування у майбутніх перекладачів професійно-орієнтованої лексичної обізнаності на сучасному етапі полягають у розвитку вміло і швидко застосовувати за різних обставин лексичне мислення студента; у розвитку мовної здатності добре і швидко міркувати, зіставляти різні думки, всебічно зважувати їх, роблячи певні висновки; у поглибленні навичок самостійної роботи з текст; удосконалювання вміння до самонавчання; у розвитку комунікативних здібностей.

Отже, беручи до уваги вище згадане, ми виділено такі педагогічні умови, що, на нашу думку, найбільш ефективно впливають на забезпечення професійної підготовки майбутніх перекладачів на засадах інтегративного підходу:

- забезпечення інтегративного підходу в формуванні професійної компетентності майбутніх перекладачів;

- стимулювання розвитку міжкультурної комунікативної компетенції майбутніх перекладачів у процесі професійної підготовки;

- реалізація інтегрованого змісту, форм та методів професійної підготовки майбутніх перекладачів для студентів спеціальності «Філолог»;

- удосконалення форм та методів самостійної роботи.

Для майбутніх перекладачів всебічним і грунтовним має бути викладання іноземної мов тому що в майбутньому їм доведеться на практиці демонструвати високий рівень володіння мовою як розмовною так і професійною, як в усній, так і в письмовій їі формах. Надзвичайно актуальним 3 огляду на цей факт видається аспект оволодіння професійною лексикою, а також лінгвокраїнознавчими реаліями стосовно на контексту (на відміну від лінгвокраїнознавчих знань, що їх отримують наші студенти впродовж усього курсу навчання в університеті (Левицька Н., 2015). Концепція викладання іноземних мов в Україні передбачає поглиблене оволодіння 
іноземною мовою, зокрема професійне (підготовка вчителів, викладачів, перекладачів іноземних мов, фрілологів-лінгвістів) і прикладне (підготовка фрахівця гуманітарного, природничого та науково-технічного профілю). На першому етапі студенти оволодівають загальнонауковою, побутовою і діловою мовою, а на другому - спеціалізованою.

Однією 3 основних фрункцій продесійної діяльності перекладача $е$ комунікативна, яка передбачає обмін інформаціею та отримання повноцінного зворотнього зв’язку. Різнорівневі комунікативні ситуації вимагають високої психолого-педагогічної компетентності. Тому всебічна комунікативна обізнаність розглядається як інтегральна якість, що об'енуе особистнісні професійні параметри. Комунікативні якості фрахового перекладача, який володіє мовою, включають такі компоненти: комунікативний - здатність брати участь у іншомовному професійному спілкуванні, здійснювати мовну активність у конкретних ситуаціях професійного спілкування; лінгвістичний - знання правил мовної та немовної поведінки у визначена: i стандартних ситуації професійного спілкування, знання національно-культурних особливостей мова якої вивчається, та вміння здійснювати свою мовну поведінку у відповідності до цих знань; методичний як здатність студента організовувати свою роботу з вивчення іноземної мови творчо, цілеспрямовано та осмислено.

Можна сказати, що іншомовна професійна комунікативна діяльність є засобом передачі фрорм культури професійної ролі та професійного досвіду. Як вид пізнавальної діяльності, комунікативна діяльність може ідентифікуватися 3 комунікативною компетентністю, що дозволяе створювати дидактичні умови, що стимулюють розвиток певних видів здібностей засобами іноземної мови (Моцар М., 2018). Профресійному перекладачу необхідно володіти фраховою термінологією на високому рівні, адже її досконале знання, доцільне застосування є запорукою успішної професійної діяльності. Формуванню термінологічної компетенції слід приділяти увагу не лише у процесі вивчення фрахових дисциплін, а й за допомогою засобів іноземної мови.

Для успішного оволодіння фраховою лексикою студентами фрілологічних фракультетів необхідно застосувати понятійно-жанровий підхід, який спрямовуеться на ознайомлення із загальними особливостями фрункціонування фрахової термінології в різних типах фрахових текстів, залежно від функціонально-стилістичного різновиду тексту і жанру. Для роботи за допомогою цього методу викладачеві необхідно чітко уявляти собі, які ознаки фахової термінології переважають в різних жанрах, як належать тій чи іншій сфрері, і що відповідають вузьким професійним сферам, а на які 3 них у першу чергу необхідно звертати увагу студентам, які опановуючи мовні спеціальності, мають оволодіти сукупністю всіх мовних засобів, що застосовуються в спеціальній галузі комунікації, гарантуючи розуміння між людьми, які працюють в даній сфері (Лавриненко О., 2011). Поєднуючи такі підходи та застосовуючи інтегративні зв'язки, можна досягти значно кращих результатів, виробити у майбутнього фахівця глибоке розуміння сутності и сесійної діяльності.

Обговорення / Discussion. Беручи до уваги те, що освітньо-кваліфрікаційна характеристика фрілолога передбачає вміння читати різнопрофрільні тексти, готовність до засвоєння спеціальних термінів, розуміння міжнародної наукової та іншої термінології, логічним є використовувати курс латинської мови як системоформувальну дисципліну в утворенні інтегративних міжпредметних зв'язків (Ребрій О., 2005). Інтеграція лінгвістичних дисциплін передбачає: з'ясування принципів міждисциплінарності та трансдисциплінарності при підборі змісту та фрорм занять з латинської та англійської (німецької, фрранцузької) мови; організацію творчого співробітництва викладачів іноземних мов; побудову скоординованої системи дій та вимог викладачів різних предметів у напрямку стимулювання використання латинської лексики в творчих наукових роботах майбутніх перекладачів (проектах, доповідях, курсових, дипломних роботах), формулюванні наукових робіт, статей (Комісаров В., 1997).

Для підготовки конкурентноспроможного фрахового перекладача необхідно включити до інтегрованого курсу таку науку як Лінгвокраїнознавство що вивчає мовні одиниці, які найяскравіше відображають культурні особливості народу - носія мови та місце його існування: реалї - визначення предметів чи явищ, характерних для певної культури та відсутніх в іншій; конотативна лексика, тобто слова, що мають однакове чи подібне основне значення, але відрізняються культурно-історичними асоціаціями; фронова лексика, яка означає предмети та явища, які мають аналоги в культурі мови, що вивчається, але відрізняються національними особливостями фрункціонування, форми, призначення предметів тощо (Болотна Т., Зубрицька О., 2007). В перекладознавстві та лінгвокраїнознавстві національна чи регіональна риса представляє собою особливу одиницю. 3 одного боку, ця риса відображає державний, економічний, географічний та культурний устрій країни, що придає їй більш вагоме значення. Але 3 іншого боку, ця риса - це слово, яке називає обєкти, характерні для життя одного народу та абсолютно чужі іншому, що дуже ускладнюе переклад, і перекладач змушений докладно описувати чи пропонувати свої неологізми. 
Отже, національні особливості, їх різноманітність є основою та об’єктом лінгвокраїнознавства, за допомогою якого намагаються зрозуміти внутрішній устрій, економічний та культурний рівень, історію країни, мова якої вивчаеться, ї̈ героїв, традиції та звичаї. Саме через реалії здаються певні риси, особливості характеру, притаманні саме цій країні, яка існуе в певну історичну епоху, тому що лексика реагуе на всі зміни суспільного життя, і це відображено в словниковому запасі країни. Успішному та швидкому засвоенню лінгвокраїнознавчого матеріалу на заняттях з іноземної мови сприяе моделювання реальних побутових ситуацій. Здійснення принципу реальності на практиці дозволить зменшити час, що є необхідним для засвоєння конкретного мовного матеріалу.

Викладання професійних дисциплін іноземними мовами базуються на низці розроблених ідей. Ставши студентами, обдаровані діти попадають у загальне середовище, спрямоване на підготовку «середнього» фахівця і часто втрачають не лише інтерес до навчання, але й задуті у загальноосвітній школі знання. Тому необхідно всіляко підтримувати і розвивати здатність цієї категорії студентів до професійного розвитку і самореалізації (Поршнева Е., 2004). Мова йде не про традиційне вивчення іноземних мов, а про надання обдарованим студентам можливості отримувати істину спеціальних знань та розвивати їх безпосередньо однією або двома іноземними мовами.

Сутність інтеграції професійної підготовки конкурентоспроможних фрахівців у вищій школі полягае у формуванні у них білінгвальної складової в професійної компетенції, яка зумовлюе здатність до професійної іншомовної комунікації, адекватної культурної самоідентифікації, вільному вибору власної позиції, активної самореалізації та культуротворчою діяльності. Інтеграція лінгвістичної фрахової підготовки - одна зі складових конкурентоспроможності фахівців у вищій школі. Це обумовлено специфікою мовних і лінгвістичних знань, яка включае велику питому вагу формування мовленневих умінь і навичок, рішення різноманітних комунікативних завдань, значення, смисли.

Для фрахівців з перекладу всебічним і грунтовним мае бути викладання окремих дисциплін іноземною мовою, адже в остаточному результаті саме їм доведеться на практиці демонструвати високий рівень володіння мовою: як розмовною, так і професійною, як в усній, так і в письмовій ії формах (Мартинюк О., 2014, с. 499). Система інтегрованих знань та умінь у змісті професійної підготовки майбутніх перекладачів забезпечуе формування конкурентоспроможного професіонала на основі сформованих інтегрованих знань, практичних умінь, навичок, а на основі цього i професійних цінностей та особистісних якостей фахівця. Інтегрування професійних знань і вмінь відбувається через ї властивості, що необхідно враховувати під час формування змісту, форм i методів професійної підготовки майбутніх перекладачів.

Методика формування знань ефективна, якщо забезпечуе, перш за все, глибину засвоєння знань (Латишев Л., 1999). Методика ефективна, якщо забезпечуе засвоення відносин знань, їх взаємозв'язків, що навчається, розумового комплексу, який засвоєний цілісно. Засвоєння знань повинне поєднуватися з активізацією і розвитком мислення студента. Теоретичне обгрунтування інтеграції знань базуеться на аналізі інтегративного потенціалу параметрів звань (величин, які характеризують властивості знання) (Козловська I., 2008) у контексті інтегративного підходу до нормування змісту освіти.

Професійні уміння перекладача полягають у гнучкому й успішному виконані професійних обов'язків в нестандартних, незвичайних, різноманітних ситуаціях. Ці уміння повинні бути не тільки автоматичні, але здійснюватися усвідомлено, при активній участі мислення, постійних розумовому контролі та оцінках, що відбувається в даній ситуації. Також повинні бути присутні елементи творчості, відшукання способів гнучкого пристосування дій, адекватних специфіці ситуації і умов (Копусь О., 2014). Властивості умінь - адекватність специфіці ситуації, свідомість, гнучкість, достатня швидкість виконання, успішність, надійність стійкість до несподіваного i незвичайного.

Професійне вміння характеризуе готовність виконувати дію (практичну і розумову) свідомо, добираючи і правильно використовую доцільні в даних умовах способи дій і досягаючи завдяки цьому високих якісних або кількісних результатів праці.

Порівнюючи інтегровані знання та вміння з предметними, можемо зробити висновок, що інтегровані є більш грунтовними. Розвиток знань та умінь характеризуеться напрямом руху знань, наявністю раптових та поступових стрибків знань. Елементи знань, які зберігають зміст, але змінюють форму залежно від ролі у змісті навчання, відіграють суттеву роль в інтегративних процесах.

Таким чином, інтегративний підхід полягає у виявленні наявного потенціалу іноземної мови неявній формі через внутрішньопредметну і міжпредметну інтеграцію знань; встановленні істота зв'язків між відносно незалежними поняттями, об’єктами та явищами іноземної мови та лінгвокраїнознавчих дисциплін; встановленні логічних взаємозв'язків між культурами різних 
народів; створенні передумов творчості мислення і власної організації знань; формуванні наскрізних понять та їх активне використання у навчальному процесі.

Висновки / Conclusions. Отже, інтеграція знань та умінь сприяе оновленню змісту професійної підготовки, передбачає постійне оновлення знань та вмінь майбутніх перекладачів. Тому ми виокремили такі особливості інтеграції знань і вмінь майбутніх перекладачів: необхідне урахування особливої ролі та місця іноземної мови у професія підготовці майбутніх перекладачів; визначення та забезпечення рівнів компетенції володіння іноземними мовами для фахівців різних спеціалізацій та освітньо-кваліфікаційних рівнів забезпечення вибору основної та додаткових мов, виходячи 3 конкретних потреб і цільового призначення у професійній діяльності фрахового перекладача; забезпечення готовності перекладацької діяльності фахівців враховуючи особливості певної галузі діяльності; інтеграція знань та умінь у процесі вивчення іноземних мов, що сприяе оптимізації теоретичного та практичного компонентів професійної підготовки майбутніх перекладачів.

\section{Список використаних джерел і літератури:}

Болотна, Т., \& Зубрицька, О. (2007). Лінгвістика та краӥнознавчий аспект у викладанні англійськоі мови. Взято з $\mathrm{http} / / /$ www.rusnauka.com/20_PRNiT_2007/Philologia/23704.doc.htm [in Ukrainian].

Гавриленко, Н. Н. (1997). Интегративная модель обучения переводу. Школа дидактики перевода. Взято с http://www.engectver.ru/Konferenciva/4s/gavrilenko.php [in Russian].

Гончаренко, С. У., \& Козловська, І. М. (1997). Теоретичні основи дидактичної інтеграції у професійній середній школі. Педагогіка і психологія. 2, 9-18 [in Ukrainian].

Гребенников, А. В. (2012). Роль интегративных курсов в развитии самоорганизации обучающихся. Историческая и соииально-образовательная мыслль, 4, 99-101 [in Russian].

Долинський, С. В. (2013). Педагогічні умови формування інформатичної компетентності майбутніх перекладачів при вивченні іноземної мови. Вища освіта України, 2 (2), 371-377 [in Ukrainian].

Козловська, I. М. (2008). Метапредметна інтеграція у змісті пробесійної освіти: метод. реком. Львів: Сполом [in Ukrainian].

Колодій, І. А. (2009). Аспекти формування інтегральної професійної компетентності у майбутніх перекладачів авіаційної галузі. Вісник післядипломної освіти, 11 (1), 112-118. Взято 3 http://nbuv.gov.ua/UJRN/Vpo_2009_11\%281\%29_16 [in Ukrainian].

Комиссаров, В. Н. (1997). Теоретические основы методики обучения переводу: [моногр.]. Москва: МГЛУ [in Russian].

Копусь, О. (2014). Формування професійної мовленневої компетентності майбутніх магістрів філології. Теоретична і дидактична фбілологія, 18, 45-51.

Лавриненко, О. О. (2011). Методика викладання перекладу: навч. посіб. Київ. КиМУ [in Ukrainian].

Латышев, Л. К., \& Провоторов, В. И. (1999). Структура и содержание подготовки переводчиков в языковом вузе: учеб. пособие для студ. вузов. Курск: РОСИ [in Russian].

Левицька, Н. В. (2015). Проблема професійної підготовки перекладачів у теоретично-педагогічних дослідженнях. Молодий вчений, 7 (2), 57-60.

Мартинюк, О. В. (2014). Становлення системи професійної підготовки спеціалізованих перекладачів: досвід США. Вісник Національної акаделї̈ Державної прикордонної служби України, 4. Взято $з$ http://nbuv.gov.ua/UJRN/Vnadps_2014_4_13 [in Ukrainian].

Моцар, М. М. (2018). Формування полікультурної компетентності майбутніх перекладачів з використання.м технологій дистанційного навчання: дис. ... канд. пед. наук: 13.00 .04 «Теорія і методика професійної освіти». Київ [in Ukrainian].

Наказний, М. О. (2015). Змістова модель організації педагогічної практики для студентів напряму «Переклад» у вищому навчальному закладі. Інновації у вищій освіті - комунікаціл та співпраия у сучасному університетському середовищі за допомогою специфбінии иифрових інструментів: [міжнар. кол. моногр.]. Дніпродзержинськ [in Ukrainian].

Павлик, О. Б. (2004). Профбесійно-педагогічна підготовка майбутніх перекладачів до використання офбіційно-ділового мовлення: дис. .... канд. пед. наук. Хмельницький [in Ukrainian].

Поршнева, Е. P. (2004). Междисииплинарньье основы базовой лингвистической подготовки специалиста-переводчика: автореф. дис. ... д-ра пед. наук: 13.00.08. Казань [in Russian].

Ребрій, О. В., \& Панченко, О. І. (2005). Методика підготовки навчальних матеріалів для майбутніх перекладачів. Вчені записки, 2, 497-505 [in Ukrainian].

Соколова, І. В. (2008). Профбесійна підготовка майбутнього вчителя-ббілолога за двома спеціальностяли: [моногр.]. Дніпропетровськ [in Ukrainian].

\section{References:}

Bolotna, T., \& Zubrytska, O. (2007). Linhvistyka ta krainoznavchyi aspekt u vykladanni anhliiskoi movy [Linguistics and Ethnographic Aspect in Teaching English]. Retrieved from http://www.rusnauka.com/20 PRNiT 2007/Philologia/23704.doc.htm [in Ukrainian].

Gavrilenko, N. N. (1997). Integrativnaya model' obucheniyia perevodu. Shkola didaktiki perevoda [Integrative Model of Translation Training. School of Translation Didactics]. Retrieved from http://www.engectver.ru/Konferenciya/4s/gavrilenko.php [in Russian]. 
Honcharenko S. U. \& Kozlovska I. M. (1997). Teoretychni osnovy dydaktychnoi intehratsii u profesiinii serednii shkoli. [Theoretical foundations of didactic integration in vocational high school]. Pedahohika $i$ psykholohiia - Pedagogy and Psychology, 2, 9-18 [in Ukrainian].

Grebennikov, A. V. (2012). Rol' integrativny'x kursov v razvitii samoorganizacii obuchayushhixsya [The Role of Integrative Courses in the Development of Students' Self-Organization]. Istoricheskaya $i$ social'noobrazovatel'naya my'sl'- Historical and Socio-Educational Thought, 4, 99-101 [in Russian].

Dolynskyi, Ye. V. (2013). Pedahohichni umovy formuvannia informatychnoi kompetentnosti maibutnikh perekladachiv pry vyvchenni inozemnoi movy [Pedagogical Conditions for the Formation of Information Competence of Future Translators in the Study of a Foreign Language]. Vyshcha osvita Ukrainy - Higher education of Ukraine, 2 (2), 371-377 [in Ukrainian].

Kozlovska, I. M. (2008). Metapredmetna intehratsiia u zmisti profesiinoi osvity [Meta-Subject Integration in the Content of Vocational Education]. Lviv: Spolom [in Ukrainian].

Kolodii, I. A. (2009). Aspekty formuvannia intehralnoi profesiinoi kompetentnosti u maibutnikh perekladachiv aviatsiinoi haluzi [Aspects of Formation of Integrated Professional Competence in Future Translators of the Aviation Industry]. Visnyk pisliadyplomnoi osvity - Bulletin of Postgraduate Education, 11 (1), 112-118. Retrieved from: http://nbuv.gov.ua/UJRN/Vpo_2009_11\%281\%29_16 [in Ukrainian].

Komissarov, V. N. (1997). Teoreticheskie osnovy' metodiki obucheniya perevodu [Theoretical Bases of Methods of Teaching Translation]. Moscow: MHLU [in Russian].

Kopus, O. (2014). Formuvannia profesiinoi movlennievoi kompetentnosti maibutnikh mahistriv filolohii [Formation of professional speech competence of future masters of philology]. Teoretychna i dydaktychna filolohiia - Theoretical and Didactic Philology, 18, 45-51.

Lavrynenko, O. O. (2011). Metodyka vykladannia perekladu [Methods of Teaching Translation]. Kyiv: KyMU [in Ukrainian].

Laty'shev, L. K., \& Provotorov, V. I. (1999). Struktura i soderzhanie podgotovki perevodchikov v yazy'kovom vuze [The Structure and Content of the Training of Translators in a Language University]. Kursk: ROSI [in Russian].

Levytska, N. V. (2015). Problema profesiinoi pidhotovky perekladachiv u teoretychno-pedahohichnykh doslidzhenniakh [The Problem of Professional Training of Translators in Theoretical And Pedagogical Research]. Molodyi vchenyi - Young Scientist, 7 (2), 57-60.

Martyniuk, O. V. (2014). Stanovlennia systemy profesiinoi pidhotovky spetsializovanykh perekladachiv: dosvid SShA [Formation of the System of Professional Training of Specialized Translators: the Experience of the USA]. Visnyk Natsionalnoi akademii Derzhavnoi prykordonnoi sluzhby Ukrainy - Bulletin of the National Academy of the State Border Guard Service of Ukraine. Retrieved from http://nbuv.gov.ua/UJRN/Vnadps_2014_4_13 [in Ukrainian].

Motsar, M. M. (2018). Formuvannia polikulturnoi kompetentnosti maibutnikh perekladachiv $z$ vykorystanniam tekhnolohii dystantsiinoho navchannia [Formation of Multicultural Competence of Future Translators with the Use of Distance Learning Technologies]. (Doctor's thesis). Kyiv [in Ukrainian].

Nakaznyi, M. O. (2015). Zmistova model orhanizatsii pedahohichnoi praktyky dlia studentiv napriamu «Pereklad» u vyshchomu navchalnomu zakladi [Semantic Model of Organization of Pedagogical Practice for Students in the Field of «Translation» in Higher Education]. Innovatsii u vyshchii osviti - komunikatsiia ta spivpratsia u suchasnomu universytetskomu seredovyshchi za dopomohoiu spetsyfichnykh tsyfrovykh instrumentivInnovations in Higher Education - Communication and Cooperation in the Modern University Environment with the Help of Specific Digital Tools. Dniprodzerzhynsk: DDTU [in Ukrainian].

Pavlyk, O. B. (2004). Profesiino-pedahohichna pidhotovka maibutnikh perekladachiv do vykorystannia ofitsiino-dilovoho movlennia [Professional and Pedagogical Training of Future Translators for the Use of Official Business Speech]. (Candidate's thesis). Khmelnytskyi [in Ukrainian].

Porshneva, E. R. (2004). Mezhdisciplinarny'e osnovy' bazovoj lingvisticheskoj podgotovki specialistaperevodchika [Interdisciplinary Bases of Basic Linguistic Training of a Specialist Translator].(Doctor's thesis). Kazan [in Russian].

Rebrii, O. V., \& Panchenko, O. I. (2005). Metodyka pidhotovky navchalnykh materialiv dlia maibutnikh perekladachiv [Methods of Preparation of Educational Materials for Future Translators]. Vcheni zapysky Scholarly Notes, 2, 497-505 [in Ukrainian].

Sokolova, I. V. (2008). Profesiina pidhotovka maibutnoho vchytelia-filoloha za dvoma spetsialnostiamy [Professional Training of Future Teachers of Philology in Two Specialties. Dnipropetrovsk [in Ukrainian].

Дата надходження статті: «20» жовтня 2020 р.

Стаття прийнята до друку: «08» грудня 2020 р.

Савка Ірина - доцент кафедри іноземних мов для гуманітарних фракультетів Львівського національного університету імені Івана Франка, кандидат педагогічних наук, доцент

Savka Iryna - Associate Professor of Foreign Languages for Humanities of Ivan Franko National University of Lviv, Candidate of Pedagogical Sciences, Assistant Professor

\section{Цитуйте цю статтю як:}

Савка, I. (2020). Педагогічні умови реалізації професійної підготовки майбутніх перекладачів на основі інтегративного підходу. Педагогічний дискурс, 29, 76-81. doi: 10.31475/ped.dys.2020.29.10.

\section{Cite this article as:}

Savka, I. (2020). Pedagogical Conditions for the Realization of Professional Training of Future Translators on the Basis of the Integrative Approach. Pedagogical Discourse, 29, 76-81. doi: 10.31475/ped.dys.2020.29.10. 